\title{
Prevalence of Fasciola spp. Among Slaughtered Livestock in Zakho City,
} Duhok Governorate - Iraq

\author{
Chira Abdullah Nerway ${ }^{1}$, Wijdan Mohammed Salih Mero², Ahmed B. Mohammed ${ }^{3}$ \\ ${ }^{1,3}$ Department of Biology, Faculty of Science, Zakho University, Zakho, Kurdistan Region, Iraq \\ ${ }^{2}$ Department of Biology, University of Zakho, Zakho (Visitor in Nawroz University), Kurdistan Region, Iraq
}

\begin{abstract}
Fascioliasis is one of the most common neglected zoonotic disease caused by Fasciola species. The current study was conducted during January to December 2019,in which five districts were selected in various parts of Duhok governorates which differ in their environmental and geographical conditions they included: Duhok city, Zakho, Shelidiza, Aqrah and Bardarash. Each slaughter house was visited once monthly to determine the rate of fascioliasis among domestic animals; cattle, sheep and goats. The infected livers were examined grossly and the bile duct and gall bladder were inspected for the presence of Fasciola species, the work was performed in Parasitology Laboratory, Biology Dept., Faculty of Science, Zakho University. Fascioliasis was diagnosed in 2.0\% (195/9757) of total slaughtered livestock, with the highest rate of infection in cattle which was 3.27\% (66/2021), followed by sheep 1.76\% (122/6932) and the lowest in goats 0.87\% (7/804). Slightly higher prevalence rate from positive cases was found in local livestock compared to imported one (2.10\% versus $1.88 \%$ ).

According to gender, males showed higher prevalence than females (2.08\% versus $1.08 \%)$. Regarding Fasciola species, among sheep and goats; the prevalence of F. hepatica was higher than Fasciola gigantica. While among cattle, F. gigantica was the most common species. With respect to parasite burden, the heaviest burden was recorded in 38.46\% (20-100 flukes/liver) of slaughtered livestock with the heaviest being in sheep (55.74\%), followed by goats $(71.43 \%)$ while lightest burden was recorded in cattle in 62.12\% (1-10 flukes/liver). Most of the liver flukes were recovered from the bile ducts (67.69 \%), followed by gall bladder $(21.54 \%)$ and the least $(10.77 \%)$ from both the bile ducts and gall bladder.
\end{abstract}

Keywords: Bile ducts, Gall bladd, Duhok.

\section{Introduction}

Fascioliasis is considered as one of the most common and economically important parasitic diseases of domestic livestock, in particular sheep, goats and cattle. The disease causes a considerable economic loss in cattle industry, mainly through mortality, liver condemnation, reduction in milk and meat production in addition to the expenditure for anthelmintic (Hillyer and Apt, 1997). The disease is caused by digenean trematodes of the genus Fasciola, commonly known as liver flukes. The most commonly implicated, species are Fasciola hepatica and Fasciola gigantica. This disease causes a serious effect to grazing animals (Torgerson, 1999). The economic losses due to fascioliasis are estimated to be more than 3.2 billion Dollars annually (Jaja et al., 2017).
Lately, fascioliasis has been well studied and concerned because of its zoonotic feature, as it is both species can infect the humans (Schweizer et al., 2005). Humans are incidental hosts and can acquire the infection by ingesting watercress or drinking water containing encysted cercariae. The illness occurs worldwide, particularly in regions with intensive sheep or cattle production. Incidence of human infection has increased over the past 20 years because of the large numbers of people and animals infected worldwide, fascioliasis causes considerable morbidity (Piedrafita et al., 2010). The life cycle of Fasciola involves the existence of snail which acts as an intermediate host that spread the disease as a consequence of infection (Mas-Coma et al., 2005). F. 
hepatica infects the snail Lymnaea truncatula, which is frequently found in cold and mild climatic regions therefore, it is common in Europe, Australia and America (Mas-Coma and Bargues, 1997). Whereas, F. gigantica is most common in sub-tropical and tropical regions of Asia and Africa (Thanh, 2012). Detection and diagnosis of fascioliasis in domestic animal depend on classical parasitology diagnosis technique such as coprological investigation besides identifying the morphological features of the parasite (Thanh, 2012). Although coprological examination is an easy and cheaper methods besides had a high specificity, but has low sensitivity especially between closely related species when using eggs morphology (Adedokun et al., 2008).

Some studies on the prevalence of fascioliasis have been performed in Iraq and they reported variable rates. In Mosul city Al-Mahmood and Al-Sabaawy (2019), reported a rate of $4 \%(17 / 425)$ in cattle, while a very high rates $54.7 \%$ and $23.71 \%$ were reported among cattle and buffalo, respectively in Thi-Qar (Gatie et al., 2018). In Kirkuk rates of 0.26\%, $1.04 \%$ and $1.16 \%$, were recorded among sheep, goats and cattle, respectively (Abass et al.,2019). In Karbala a rate of $3.61 \%$ was recorded among infected cows (Hussain et al., 2017). Although many epidemiological studies were performed on the prevalence of Fasciola among domestic animals in the country, most of them dealt with one species of animals and in one area of the country. Hence, the present investigation estimated the rate of fascioliasis among cattle, sheep and goats in different districts of Duhok and also involved the local breed and the imported one to get more inside about the prevalence of fascioliasis and to correlate the subsequent data with some risk factors.

\section{Materials and Methods}

\subsection{Study Aera and Sample Collection}

The study area included five districts in various parts of Duhok governorates which differ in their environmental and geographical conditions they included: Duhok city, Zakho, Shelidiza, Aqrah and Bardarash. The study was conducted between January and December of 2019, a monthly visit was made to the slaughter house of each district of Duhok governorate. Liver flukes were isolated from the gall bladder, bile ducts and both of them of 195 infected livestock (122 sheep, 7 goats and 66 cattle/9757 examined) at different abattoirs. The infected livers were examined grossly and the bile duct and gall bladder were inspected for the presence of Fasciola species by applying the routine inspection procedures to internal organ. Several incisions were made in different parts of the liver for confirming the presence of liver flukes in the parenchyma of liver, liver pieces were pressed in order to squeeze the flukes out from the tissue and bile ducts. Each isolated liver fluke was examined and classified on the basis of shape and size (Soulsby, 1982). Regarding the source of imported animals, the sheep and cattle were imported mostly from neighboring countries such as Syria, Turkey, Iran and some from other countries like India, Brazil, Romania, and Vietnam. While the source of all goats was from Kurdistan region-Iraq. The numbers of total animals slaughtered and infected and non-infected animals in each district were carefully recorded on standardized data sheets designed for the study.

\subsection{Data Analysis}

The statistical package for social sciences (SPSS) (Kauffman et al., 2000) software was used for analyzing the data. The relative proportions were calculated with a confidence interval of $95 \%$. To determine the association between variables, the chisquared $\left(\mathrm{x}^{2}\right)$ test was used; a $p$-value $<0.05$ was considered significant and more than that considered non-significant.

\subsection{Result and Discussion}

Table (1) shows the prevalence of Fasciola spp. among slaughtered livestock, the overall rate of infection was $2.00 \%(195 / 9757)$. According to the animal species, cattle showed the highest rate of infection $3.27 \%$ 
(66/2021), followed by sheep 1.76\% (122/6932), while only $0.87 \%(7 / 804)$ of goats were infected. The overall, rate of fascioliasis was slightly higher among the local livestock as compared to imported one, which was $2.10 \%(111 / 5294)$ vs $1.88 \%(84 / 4463)$, respectively. Furthermore, local cattle showed the highest rate $(11.63 \%)$, followed by local sheep (2.04\%). In general, statistical analysis of the results showed the presence of significant difference $(P<0.05)$ in the overall rates of infection between animals' species and source.

In this study, the highest prevalence of infection was seen among slaughtered cattle $(3.27 \%)$, which is close to the rates reported in other studies such as, in Erbil a rate of $3.44 \%$ in cattle (Koyee et al., 2011) and in Kirkuk (2.63\%) by Rasheed and Kadir (2008). Regarding the rate of fascioliasis among infected sheep, $1.76 \%$ is much lower than the rate reported in a study by Meerkhan and Razak (2013) as they reported a rate of $16.8 \%$ in sheep in Duhok. Also, very high rates in sheep have been reported from Dewania, Babylon and Abu-Ghraib district, which were 76.6\%, 72\%, 35\% and 12.73\% (Al-Khafaj, 2011; Abass et al., 2018; Abdalnabi, 2012 and Oleiwi et al., 2017), respectively. Regarding the rate of fasciolosis among infected goats, in the current study the lowest rate was reported $(0.87 \%)$, which somewhat near the rate reported by Abass et al. (2019) in Kirkuk which was 0.7\%. Whereas, Abdalnabi (2012) in Babylon and Koyee et al. (2011) in Erbil, recorded rates of $68.4 \%$ and $3.62 \%$, respectively in goats. Higher rates of fascioliasis than that of the present study have been reported in neighbor countries such as Iran $(66.6 \%$ in cattle, $93 \%$ in sheep) (Akca et al., 2014) and Turkey (31.4\% in sheep) (Acici et al., 2015).

These results confirm that the prevalence of fascioliasis is much lower than in the neighboring countries in spite of the lack of reliable anthelmintic controlling regimes in Iraq during the last decade. The highest rate of fasciolosis among cattle followed by sheep and lowest among goats could be due to the difference in the grazing style of animals on grassland as goats eat leaves and heaths in mountain areas, high percentage of fasciolosis among cattle may be due to that cattle were more frequently grazing near springs, pools, streams and river where naturally snails are present, hence getting more contacts with encysted metacercariae, regarding sheep they often graze on open land where getting less chance of contact with infected metacercariae and therefore the risk of their infection with fasciolosis is reduced (Kordshooli et al., 2017).

With respect to animal source, in general, the overall rate of fascioliasis among local livestock was slightly higher than imported one $(2.10 \%$ vs $1.88 \%)$, furthermore, local sheep and cattle also showed higher rates than imported one $(2.04 \%$ vs $1.28 \%)$ in sheep and (11. $62 \%$ vs $2.70 \%)$ in cattle, respectively. In this regard the present results are consistent with the studies conducted in Egypt by Hussein and Khalifa (2010) as they reported high rate of infection (78.7\%) from local cow and lower (21.3\%) from imported one. In Ethiopia Abebaw et al. (2012) reported higher rate of infection in local sheep (72.65\%) than imported sheep (44\%). Also, in Nigeria Aliyu et al. (2014) reported high rate of fascioliasis among local cattle breed $(15.6 \%)$ with no infection among the imported one.

On the other hand, in Saudi Arabia, Sanad and AlMegrin (2005) reported higher infection rate $(15.1 \%)$ with fascioliasis among imported sheep than the local ones $(4.96 \%)$. In another study also in Saudi Arabia, Degheidy and Al-Malki, (2013) reported higher prevalence of fascioliasis among imported cattle which was $8.6 \%$. While in Turkey, Yildirim et al. (2007) they did not find any significant association among sheep infected with F. hepatica and the type of breed. These differences among local and imported breed may be due to local geographic disruption and low levels of awareness of these infectious diseases 
among domestic animals, or attributed to grazing in areas that could be heavily infested with intermediate host (Aliya et al., 2014).

The highest rate of fasciolosis in sheep and goats was reported at Shelidiza abattoir which were $6.58 \%$ and $1.64 \%$, respectively. While the highest rate of infection for cattle was at Zakho abattoir which was 3.91\%. With significant differences between the rate of infection and types of animal's slaughtered in different slaughter houses $(P<0.05)$ as shown in table (2).

Table 1: the prevalence of Fasciola spp. in sheep, cattle and goats of both sources slaughtered in Duhok Governorate

\begin{tabular}{|c|c|c|c|c|c|c|c|c|}
\hline \multirow[b]{3}{*}{ 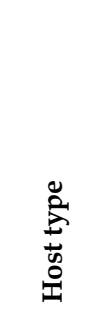 } & \multirow{3}{*}{ 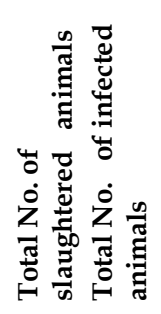 } & \multirow{3}{*}{ 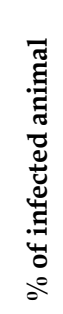 } & \multicolumn{6}{|c|}{ Source of Animal } \\
\hline & & & \multicolumn{3}{|c|}{ Imported } & \multicolumn{3}{|c|}{ Local } \\
\hline & & & 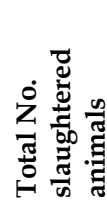 & 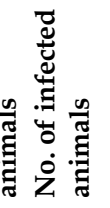 & 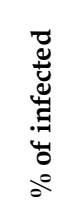 & 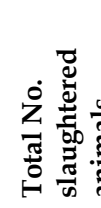 & 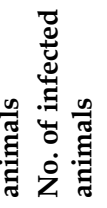 & 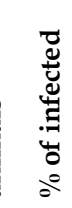 \\
\hline Sheep & 6932122 & 1.76 & 2571 & 33 & 1.28 & 4361 & 89 & 2.04 \\
\hline Goats & $\begin{array}{ll}804 \quad 7 \\
\end{array}$ & 0.87 & & & 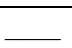 & 804 & 7 & 0.87 \\
\hline Cattle & 202166 & 3.27 & 1892 & 51 & 2.70 & 129 & 15 & 11.63 \\
\hline Total & 9757195 & 2.00 & 4463 & 84 & 1.88 & 5294 & 111 & 2.10 \\
\hline
\end{tabular}

Aclear variation in the prevalence of fasciolosis among different districts of Duhok governorate, was observed which can be attributed to many factors such as geographical variations, soil composition, climate conditions, besides the life cycle of Fasciola spp. in a given area depends on the availability of the snail hosts, which dramatically influenced by the temperature and the amount of Rainfall, since the development of the eggs and the intramolluscan stages of the parasite depends on the environmental conditions, in general all these factors play an important role in the prevalence of fascioliasis among definitive hosts in a given area (Yadegari et al., 1990; Torgerson and Claxton, 1999; Rokni 2008; Kooshan et al., 2010).
Regarding the gender of infected animal, males showed a higher rate of fascioliasis than females (Table 3), The overall rate in males was $2.08 \%$ versus $1.08 \%$ in females. Regarding livestock species, the highest rate was reported among female cattle, which was $3.28 \%$. followed by sheep (1.83\%). Statistically significant difference $(p<0.05)$ was observed in the rate of fascioliasis in relation to the gender of infected animals, Similarly, Asnake et al. (2018) in Ethiopia reported higher rate of fascioliasis in male sheep than females which were $17.3 \%$ vs $15.6 \%$. Magaji et al. (2014) stated that the prevalence of fascioliasis in cattle revealed more common in males than in females and attributed it to the disparity in susceptibility to helminth infection between the both sexes which could be due to the differences in the host intrinsic factors

Table 2: The prevalence of Fasciola spices. among slaughtered livestock in Duhok governorate slaughter houses.

\begin{tabular}{|c|c|c|c|c|}
\hline $\begin{array}{l}\text { Type of } \\
\text { livestock }\end{array}$ & $\begin{array}{l}\text { Slaughter } \\
\text { house } \\
\text { name }\end{array}$ & $\begin{array}{l}\text { No. } \\
\text { slaughtered }\end{array}$ & $\begin{array}{l}\text { No. } \\
\text { infected }\end{array}$ & $\begin{array}{l}\% \text { of } \\
\text { infection }\end{array}$ \\
\hline \multirow{5}{*}{ Sheep } & Duhok & 3443 & 79 & 2.29 \\
\hline & Zakho & 2653 & 19 & 0.72 \\
\hline & Aqrah & 676 & 15 & 2.22 \\
\hline & Shelidiza & 76 & 5 & 6.58 \\
\hline & Bardarash & 84 & 4 & 4.76 \\
\hline $\begin{array}{l}\text { Total of } \\
\text { sheep }\end{array}$ & & 6932 & 122 & 1.76 \\
\hline \multirow{5}{*}{ Goats } & Duhok & 146 & 0 & 0 \\
\hline & Zakho & 253 & 1 & 0.40 \\
\hline & Aqrah & 323 & 5 & 1.55 \\
\hline & Shelidiza & 61 & 1 & 1.64 \\
\hline & Bardarash & 21 & 0 & 0 \\
\hline $\begin{array}{l}\text { Total of } \\
\text { goats }\end{array}$ & & 804 & 7 & 0.87 \\
\hline \multirow{5}{*}{ Cattle } & Duhok & 370 & 9 & 2.43 \\
\hline & Zakho & 1022 & 40 & 3.91 \\
\hline & Aqrah & 181 & 6 & 3.31 \\
\hline & Shelidiza & 157 & 3 & 1.91 \\
\hline & Bardarash & 291 & 8 & 2.75 \\
\hline \multicolumn{2}{|l|}{$\begin{array}{l}\text { Total of } \\
\text { cattle }\end{array}$} & 2021 & 66 & 3.27 \\
\hline \multicolumn{2}{|l|}{ Total No } & 9757 & 195 & 2.00 \\
\hline \multicolumn{5}{|c|}{$\begin{array}{l}\mathrm{P}<0.05 \text { analyzed using the SPSS software using the } \\
\text { chi-squared }(\mathrm{x} 2) \text { test }\end{array}$} \\
\hline
\end{tabular}

(genetics, physiology) or the number of female animal's slaughtered is lesser than males besides that the vast majority of females are kept for breeding and milk production (Magaji et al., 2014; Asnake et al., 2018). 
Table 3: The prevalence of Fasciola species according to gender

\begin{tabular}{|c|c|c|c|c|c|c|}
\hline \multirow{2}{*}{ Host } & \multicolumn{3}{|c|}{ Male } & \multicolumn{3}{|c|}{ Female } \\
\hline & $\begin{array}{l}\text { No. of } \\
\text { slaughter }\end{array}$ & $\begin{array}{l}\text { No. of } \\
\text { infective }\end{array}$ & $\%$ & $\begin{array}{l}\text { No. of } \\
\text { slaughter }\end{array}$ & $\begin{array}{l}\text { No. of } \\
\text { infective }\end{array}$ & $\%$ \\
\hline Sheep & 6216 & 114 & 1.83 & 716 & 8 & 1.12 \\
\hline Goats & 734 & 7 & 0.95 & 70 & 0 & 0.00 \\
\hline Cattle & 1977 & 65 & 3.29 & 44 & 1 & 2.27 \\
\hline Total & 8927 & 186 & 2.08 & 830 & 9 & 1.08 \\
\hline $\begin{array}{l}<0 \\
\text { quare }\end{array}$ & $\begin{array}{l}\text { analyzed } \\
\text { x2) test }\end{array}$ & using th & & soft & using & 1 \\
\hline
\end{tabular}

Fasciola hepatica was recorded at a rate of $66.15 \%$ $(129 / 195)$ of total infection, with the highest being in sheep $59.49 \%$ (116/195), while lower rates of 3.59\% $(7 / 195)$ in cattle and 3.08\% (6/195) in goats. Fasciola gigantica was reported in cattle only at a rate of $18.97 \%$ (37/195), while single infections with $F$. gigantica was not recorded in sheep and goats. Furthermore, mixed infections with both species were recorded at a rate of $14.87 \%(29 / 195)$ with the highest being in cattle, in $11.28 \%(22 / 195)$, as shown in table (4). Hence significant difference was observed among species of Fasciola in sheep, cattle and goats $(\mathrm{p}<0.05)$.

The present results agreed with other studies, in which F. hepatica was most prevalent in sheep and goats (Yusuf et al., 2016; Piri et al., 2018) and Fasciola gigantica was more common among cattle (Abunna et al., 2009). This indicate high susceptibility of sheep to F. hepatica than F. gigantica, this might be due to several reasons such as, the biochemical characteristics of Fasciola and the immune response of the host against fasciolosis. Fasciola hepatica showed effective defenses mechanisms against nonspecific immune response (free radical killing by macrophages or eosinophils) (Meeusen and Piedrafita, 2003; Pleasance et al., 2011).

Hence non-specific immune cells such as eosinophils play a major role against $F$. gigantica than $F$. hepatica in infected sheep. Furthermore, the excretory/secretory products (ESPs) of F. gigantica stimulate the immune response of the $\mathrm{T}$ cells, $\mathrm{B}$ cells, NK cells against $F$. gigantica in early stage of infection and as a consequence an early proliferation of T-helper cell against F. gigantica occur which may lead to macrophages activation and resulting in elimination of juvenile F. gigantica (Meeusen and Piedrafita, 2003; Zhang et al., 2004).

Regarding the parasites burden among different types of slaughtered animals, the heaviest burden $(>20-100)$ per host liver was recorded in $38.46 \%$ (75/195) of slaughtered livestock, with the heaviest being in sheep which was $55.74 \%$ (68/122). While $71.43 \%(5 / 7)$ of goats had the moderate worm burden and $62.12 \%(41 / 66)$ of cattle had the lightest worm burden. Statistical analysis showed the presence of significant relationship $(\mathrm{P}<0.05)$ between the number of Fasciola species and the types of infected animals.

Table: 4 The rate of infection with Fasciola species according to host type.

\begin{tabular}{|c|c|c|c|}
\hline $\begin{array}{l}\text { Species of } \\
\text { Fasciola }\end{array}$ & Host & No. of infected & $\begin{array}{l}\% \text { of } \\
\text { infection }\end{array}$ \\
\hline \multirow[t]{3}{*}{ F. hepatica } & Sheep & 116 & 59.49 \\
\hline & Goats & 6 & 3.08 \\
\hline & Cattle & 7 & 3.59 \\
\hline \multicolumn{2}{|c|}{ Total F. hepatica infections } & 129 & 66.15 \\
\hline \multirow{3}{*}{$\begin{array}{l}\text { F. gigantica } \\
\text { only }\end{array}$} & Sheep & 0 & 0 \\
\hline & Goats & 0 & 0 \\
\hline & Cattle & 37 & 18.97 \\
\hline $\begin{array}{l}\text { Total } F . \\
\text { infections }\end{array}$ & gigantica & 37 & 18.97 \\
\hline \multirow{3}{*}{$\begin{array}{l}\text { Mixed } \\
\text { infection }\end{array}$} & Sheep & 6 & 3.08 \\
\hline & Goats & 1 & 0.51 \\
\hline & Cattle & 22 & 11.28 \\
\hline \multicolumn{2}{|c|}{ Total of mixed infections } & 29 & 14.87 \\
\hline \multicolumn{2}{|l|}{$\begin{array}{l}\text { Total } \\
\text { Infections }\end{array}$} & 195 & 100 \\
\hline \multicolumn{4}{|c|}{$\begin{array}{l}\mathrm{P}<0.05 \text { analyzed using the SPSS software using the chi- } \\
\text { squared }(\mathrm{x} 2) \text { test }\end{array}$} \\
\hline
\end{tabular}

The heavy burden of liver flukes observed in sheep in this study, may be due to that most slaughtered sheep were young aged and young animals usually are more susceptible to infection with heavy burden of parasites. while most infected cattle carry light burden of parasites with a ratio of $62.12 \%$, this may be due to that cattle have more immune response against 
invasion with liver flukes compared to sheep and goats (Mulcahy et al., 1999; Phiri et al., 2006).

Table 5: Number of parasites isolated (burden) from each infected animal

\begin{tabular}{|c|c|c|c|c|}
\hline $\begin{array}{c}\text { Types } \\
\text { of } \\
\text { animals }\end{array}$ & $\begin{array}{c}\text { No. of } \\
\text { animals } \\
\text { Infected }\end{array}$ & $\begin{array}{l}1-10 \\
\text { Light }\end{array}$ & $\begin{array}{c}>10-20 \\
\text { Moderate }\end{array}$ & $\begin{array}{l}>20-100 \\
\text { Heavy }\end{array}$ \\
\hline Sheep & 122 & $\begin{array}{l}27 / 122 \\
(22.13)\end{array}$ & $\begin{array}{l}32 / 122 \\
(26.23)\end{array}$ & $\begin{array}{r}68 / 122 \\
(55.74)\end{array}$ \\
\hline Goats & 7 & $2 / 7$ (28.5) & $5 / 7(71.43)$ & 0 \\
\hline Cattle & 66 & $41 / 66(62.12)$ & $18 / 66(27.27)$ & $7 / 66(10.60)$ \\
\hline Total & 195 & $70 / 195(35,90)$ & $55 / 195(28.21)$ & 75/195(38.46) \\
\hline
\end{tabular}

With respective to the location of the parasites within the infected organ (bile ducts and gall bladder) of infected animals, most of the liver flukes were recovered from the bile ducts $(67.69 \%)$ followed by gall bladder $(21.54 \%)$ and the least $(10.77 \%)$ from both the bile ducts and gall bladder. Regarding animal species, in $85.71 \%$ of infected goats, the parasites were recovered from the bile ducts, followed by cattle in $72.72 \%$ and in $63.93 \%$ of sheep. Statistically nonsignificant difference was observed between the location of the parasites and the types of infected animals as shown in table (6).

Table 6: Prevalence of Fasciola species according to parasite location

\begin{tabular}{lllll}
\hline \hline $\begin{array}{l}\text { Types } \\
\text { animals }\end{array}$ & $\begin{array}{l}\text { of No. } \\
\text { infected } \\
\text { animals }\end{array}$ & $\begin{array}{l}\text { of Bile duct } \\
\text { No. (\%) }\end{array}$ & $\begin{array}{l}\text { Gall } \\
\text { bladder } \\
\text { No. }(\%)\end{array}$ & $\begin{array}{l}\text { Bile } \\
\text { bladder No. } \\
\text { blucts } \\
(\%)\end{array}$ \\
\hline Sheep & 122 & $78(63.93)$ & $29(23.77)$ & $15(12.30)$ \\
\hline Goats & 7 & $6(85.71)$ & $1(14.29)$ & 0 \\
\hline Cattle & 66 & $48(72.72)$ & $12(18.18)$ & $6(9.09)$ \\
\hline Total & 195 & 132 & $42(21.54)$ & $21(10.77)$ \\
& & $(67.69)$ & & \\
\hline P value $=0.514$ analyzed sing the SPSS software using the \\
chi-squared $(\times 2)$ test
\end{tabular}

Most of Fasciola species in this study were isolated from the bile ducts of cattle, sheep and goats than other organs. Since the bile duct is the main organ for maturation of adult flukes, especially in light and moderate burden of parasites. Gall bladder of infected animals carries the parasites in case of heavy burden of liver flukes as shown in the case of infected sheep (table 6). The percentage of Fasciola species recovered from bile duct of cattle was $72.7 \%$ was slightly higher than that recovered from the bile ducts of sheep $63.9 \%$ because of grazing style of cattle which is different from that of sheep, where cattle frequently spend more of their life near rivers and pools area where there are a plenty of vegetations on which the cercariae can encyst, hence they have more chance to acquire infection (Kordshooli et al., 2017; Takeuchi-Storm et al., 2018). Adult flukes and their eggs may trap in the bile duct because of intensive calcification of bile duct which more commonly occurs in cattle after several week of infection, hence most infected cattle have light burden of liver flukes compared to other domestic animals (Phiri et al., 2006; Bouvry \& Rau 1986).

In conclusion, in Duhok governorate, both F. hepatica and F. gigantica were isolated from local and imported slaughtered livestock. Moreover, fascioliasis was more prevalent in cattle. Therefore, strategic prevention should be initiated by regular deworming of local breed before and after rainy season in order to control the disease in snail host. In addition, proper inspection at abattoirs should be intensified and quarantine regulations should address the careful inspection of live imported animals to avoid the introduction of exotic parasites.

\section{References:}

1. Abass, K. S., Ibrahim, E. K., Khalaf, R. N., and Esmail, R. H. (2018). Prevalence of Liver Fluke Infections in Slaughtered Animals in Kirkuk Province. Iraq. J Anim Sci Livest Prod, 2(2):05.

2. Abass, K. S., Mohammed, N. S., Taleb, M., \& Raheem, Z. S. (2019). Study of bovine and ovine pulmonary and hepatic abscessation at Kirkuk abattoir. Plant Archives, 19(2), 1640-1644.

3. Abdalnabi, R. A. (2012). Epidemiological study on Fasciola hepatica in children and animals at Babylon city. Al-Mustansiriyah Journal of Sciences, 23(6), 19-26.

4. Abebaw, S., Berhanu, A., Chanie, M. \& Fentahun, T. (2012). Prevalence, infectivity rate and prospective determinants of ovine fasciolosis in Wadla District, Northeast Ethiopia. European Journal of Applied Sciences.4(6): 232-237.

5. Abunna, F., Asfaw, L., Megersa, B. \& Regassa, A. 
(2010). Bovine fasciolosis: coprological, abattoir survey and its economic impact due to liver condemnation at Soddo municipal abattoir, Southern Ethiopia. Tropical Animal Health and Production. 42(2): 289-292.

6. Adedokun, O. A., Ayinmode, A. B. \& Fagbemi, B. O. (2008). A comparative study of three methods for detecting Fasciola infections in Nigerian cattle. VETERINARSKI ARHIV.78(5):411-6.

7. Aliyu, A. A., Ajogi, I. A., Ajanusi, O. J. \& Reuben, R. C. (2014). Epidemiological studies of Fasciola gigantica in cattle in Zaria, Nigeria using coprology and serology. Journal Public Health Epidemiol. 6(2):85-91.

8. Al-Khafajy, A. M. A. (2011). Detection of fascioliasis in sheep and cattle by using ELISA technique. AlQadisiyah Journal of Veterinary Medicine Sciences.10(1): 131-135.

9. Al-Mahmood, S. S. \& Al-Sabaawy, H. B. (2019). Fasciolosis: grading the histopathological lesions in naturally infected bovine liver in Mosul city. Iraqi Journal of Veterinary Sciences. 33(2):379-387.

10. Asnake, A., Wube, A., Hirpa, A., Yehualaw, B., Jemberu, A. \& Mekonnen, B.(2018). Prevalence of Fasciolosis in small ruminants and associated risk factors in and around Mekelle. Advances in Biological Research. 12 (3): 97-103.

11. Bouvry, M. \& Rau, M. E. (1984). Paramphistomum spp. in dairy cattle in Quebec. The Canadian Veterinary Journal. 25(9): 353-356.

12. Degheidy, N. S., Sharaf, E. M. \& Al-Malki, J. S. (2013). The incidence of fascioliasis and some types of bacteria incurred causing lack meat and livers quality of slaughtered animals at Al-Taif, KSA. Assiut Vet Med Journal.59(139): 136-41.

13. Gatie, J. A., Nejiban, Z. S., Abed, K. M., Abbas, R. A., Hadi, R. M., Abdul-Sattar, M. A. \& Mohsen, Y. F. (2018). Prevalence of gastrointestinal parasites in cattle and buffaloes in Thi-Qar Province, South of Iraq. Basrah Journal of Veterinary Research. 17(3):847856.

14. Hillyer, G. V., \& Apt, W. (1997). Food-borne trematode infections in the Americas. Parasitology today. 3(13): 87-88.

15. Hussain, K. L., \& Zghair, Z. R. (2017). Prevalence of fasciolosis in ruminant in Karbala city. Journal of Entomology and Zoology Studies.5(5): 364-369

16. Hussein, A. N. A. \& Khalifa, R. M. (2010). Fascioliasis prevalence among animals and human in Upper Egypt. Journal of King Saud University-Science. 22(1): 15-19.

17. Jaja, I. F., Mushonga, B., Green, E. \& Muchenje, V. (2017). Financial loss estimation of bovine fasciolosis in slaughtered cattle in South Africa. Parasite epidemiology and control. 2(4): 27-34.

18. Kauffman, S. A. (2000). Investigations. Oxford University Press., USA

19. Kobra, P. I. R. I., Saidijam, M., Maghsood, A., Matini, M., \& Fallah, M. (2018). Prevalence of animal fasciolosis and specification of Fasciola spp. isolated from sheep, goats and cattle by molecular method: Hamadan province, west of Iran. Iranian journal of parasitology, 13(4), 524

20. Kooshan, M., Tabar, G. R. H., \& Naghibi, A. (2010). Use of somatic and excretory-secretory antigens of Fasciola hepatica in diagnosis of sheep by ELISA. AmericanEurasian Journal of Agricultural and Environmental Science.7(2): 170-175.

21. Kordshooli MS, Solhjoo K, Armand B, Dowlatkhah H, Jahromi ME. (2017). A reducing trend of fasciolosis in slaughtered animals based on abattoir data in South of Iran. Vet World. 10(4):418-423.

22. Koyee, Q. M., Mustafa, S. O., \& Ahmed, H. A. (2011). Prevalence of some parasitic helminths among slaughtered ruminants (sheep, goats and cattle) in Hawler slaughter house during 2010. In Hawler, Kurdistan Region, Iraq 4th International Scientific Conference Salahaddin University, Erbil-Iraq10:1-3.

23. Magaji, A. A., Ibrahim, K., Salihu, M. D., Saulawa, M. A., Mohammed, A. A. \& Musawa, A. I. (2014). Prevalence of fascioliasis in cattle slaughtered in Sokoto metropolitan abattoir, Sokoto, Nigeria. Advances in Epidemiology., Vol. 2014, Article ID 247258, :1-5, doi10.1155

24. Mas-Coma, S., Bargues, M. D., \& Valero, M. A. (2005). Fascioliasis and other plant-borne trematode zoonoses. International journal for parasitology. 35(1112):1255-1278.

25. Mas-Coma, S., Bargues, M.D. 1997. Human liver flukes: a review. Research and Reviews in Parasitology. 57(35): 145-218.

26. Meerkhan, A. A. \& Razak, A. H. (2013). The differences between direct examination and enzyme linked immunosorbent assay (ELISA) test, during the diagnosis of fasciolosis in Jaundiced slaughtered sheep in Duhok Abattoir, Kurdistan Region of Iraq. International Journal of Chemical, Environmental \& Biological Scienc.1(5): 707-709.

27. Meeusen, E. N. \& Piedrafita, D. (2003). Exploiting natural immunity to helminth parasites for the development of veterinary vaccines. International journal for parasitology.33(11): 1285-1290.

28. Mulcahy, G., O'connor, F., Clery, D., Hogan, S. F., Dowd, A. J., Andrews, S. J. \& Dalton, J. P. (1999). Immune responses of cattle to experimental antiFasciola hepatica vaccines. Research in veterinary science. 67(1): 27-33.

29. Oleiwi, K. I., Hussein, Z. S., \& Salman, K. O. (2017). Detection of Fasciola hepatica in Abu-Ghraib district (Iraq). Journal of Entomology and Zoology Studies.5(6): 1068-1072.

30. Phiri, A. M., Phiri, I. K., Sikasunge, C. S., Chembensofu, M. \& Monrad, J. (2006). Comparative fluke burden and pathology in condemned and non-condemned cattle livers from selected abattoirs in Zambia. The Onderstepoort journal of veterinary research.73(4): 275-281.

31. Piedrafita, D., Spithill, T. W., Smith, R. E. \& Raadsma, 
H. W. (2010). Improving animal and human health through understanding liver fluke immunology. Parasite immunology. 32(8):572-581.

32. Pleasance, J., Raadsma, H. W., Estuningsih, S. E., Widjajanti, S., Meeusen, E. \& Piedrafita, D. (2011). Innate and adaptive resistance of Indonesian Thin Tail sheep to liver fluke: A comparative analysis of Fasciola gigantica and Fasciola hepatica infection. Veterinary parasitology. 178(3-4): 264-272.

33. Rasheed,S.A. \& Kadir, M.A. (2008). Prevalence of some parasitic helminths among slaughtered ruminants in Kirkuk slaughter house, Kirkuk, Iraq. Iraqi journal of veterinary Sciences.22(2): 81-85.

34. Rokni, M. B. (2008). The present status of human helminthic diseases in Iran. Annals of Tropical Medicine \& Parasitology. 102(4): 283-295.

35. Sanad, M. and Al-Megrin, W. (2005): Fascioliasis among local and imported sheep in KSA: Parasitological and serological diagnosis. J. Egyptian Society of Parasitology. 35:1121- 1134.

36. Schweizer, G., Braun, U., Deplazes, P. \& Torgerson, P. R. (2005). Estimating the financial losses due to bovine fasciolosis in Switzerland. Veterinary Record. 157(7): 188-193.

37. Soulsby EJL (1982) Helminths, arthropods and protozoa of domesticated animals, 7 th ed. Bailliere and Tindal, London, pp 771-773.

38. Takeuchi-Storm, N., Denwood, M., Petersen, H. H., Enemark, H. L., Stensgaard, A. S., Sengupta, M. E. \& Thamsborg, S. M. (2018). Patterns of Fasciola hepatica infection in Danish dairy cattle: implications for onfarm control of the parasite based on different diagnostic methods. Parasites \& vectors. 11(1): 674-678.

39. Thanh, N. T. (2012). Zoonotic fasciolosis in Vietnam: Molecular identification and geographical distribution (Doctoral dissertation, Tesis de Doctorado, Ghent University, Bélgica).

40. Torgerson, P. and Claxton, J. (1999) Epidemiology and Control: Fasciolosis. CAB International Publishing, UK. p113-149.

41. Yadegari, D., Forghanparast, K. and Assmar, M. (1990) Investigation of an epidemic of fascioliasis in north Iran. Bulletin de la Société française de parasitology. 8 (2): 868-876.

42. Yildirim, A., Ica, A., Duzlu, O. \& Inci, A. (2007). Prevalence and risk factors associated with Fasciola hepatica in cattle from Kayseri province, Turkey. Revue de medicine veterinaire. 158(12): 613-617.

43. Zhang, W., Moreau, E., Huang, W. \& Chauvin, A. (2004). Comparison of humoral response in sheep to Fasciola hepatica and Fasciola gigantica experimental infection. Parasite Journal. 11(2): 153-159. 